\title{
Research on Sponge City Construction in Lin Yi City
}

\author{
Chaowen Ji \\ The School of Architectural \\ Linyi University \\ Linyi, China \\ jichaowen@lyu.edu.cn
}

\author{
Lili Li \\ The School of Architectural \\ Linyi University \\ Linyi, China \\ lilili@lyu.edu.cn
}

\begin{abstract}
Sponge city is a new national strategy of urban planning to solve urban flooding in China. Lin Yi city is the third largest city in Shandong Province. Precipitation in Lin Yi city is mainly concentrated in the summer, the ground is located in the plains, but the river system is developed. The foundation of $\mathrm{Lin} \mathrm{Yi}$ city construction is weak, Lin Yi city must be selected according to local conditions, the selection of sponge, scientific planning and urban construction, the construction of the first priority sponge city demonstration projects, etc, which has strong demonstration significance and a certain reference to China's eastern two or three line city construction.
\end{abstract}

Keywords-Lin Yi city; sponge city; ecological factor; construction

\section{INTRODUCTION}

In recent years, because of climate change, environmental carrying capacity and human impact on the reasons, China's urban water ecological facing two extremes, one hand is severe water logging in many cities, the city "to see the sea" phenomenon is becoming more and more frequent, storm water management become affect the city's security risks; on the other hand is the most of the city is in a serious shortage of water resources, a serious shortage of water resource supply. ${ }^{[1]}$ Therefore, China's urban health sustainable development, we must repair the urban water ecology. Sponge city construction is a path to repair the city water ecology.

Sponge essence of the city is to change the traditional concept of urban development, implementation and resources and the environment Coordinated development. ${ }^{[2]}$ The sponge city is through the construction and roads, green square, lake water carriers such as infiltration, stagnation, storage, net, etc. The ecological technology to realize the natural accumulation, rainwater infiltration, purification function, emphasis on the concept of low impact development integration of city water resources, the establishment of the new city development model, ${ }^{[3]}$ to achieve the goal of coordinated development of resources and environment, as an ecological approach, is built upon multi-scale hydro ecological infrastructure to provide an integrated solution to the prominent water problems in urban and rural areas of China. ${ }^{[4]} \mathrm{We}$ study the ecological environment of the city, and analyze the important factors that affect the city's "sponge" function in the city ecological environment.

Lin Yi city has a glorious history and culture with the famous military strategist Liang Zhuge in Three Kingdoms period, calligrapher Xizhi Wang in the Eastern Jin Dynasty and Gaoqing Yan, Zhenqing Yan in Tang Dynasty as well. Since reform and opening, with the rapid development of trade and logistics industry, Lin Yi city has got the rapid development in the economic, social aspect. Lin Yi city won the National Civilized City, National Garden City, Chinese urban and rural construction model City and so on.

Lin Yi city is located in the Yi River alluvial plain, continental monsoon climate zone in North China; Since the reform and opening up, Lin Yi city from a population of 400000 people, built a city area of 33 Square kilometers (1994) of small or medium cities rapidly growing into a large city (2012) where there are 1850000 population, built urban area of 202 Square kilometers, Lin Yi city leisure area, roof and road green belt and excessive hardening, changed Lin Yi city ecology, Lin Yi city most of the rainfall runoff formation, more than 40 water logging disaster, urban water ecological deterioration. This paper takes Lin Yi city as the object to carry on the construction of the sponge City; It has strong demonstration significance and a certain reference function to the construction of the sponge city in the north of our country.

\section{ECOLOGICALFACTOR IN LIN YI CITY}

Sponge city to deal with urban problems are mainly urban rainwater, Foreign related ideas mainly include: United States of low impact development, best management practice, green infrastructure and green storm water infrastructure ${ }^{; 4}$ Australian water sensitive urban design; Britain's sustainable urban drainage system; Germany's storm water harvesting and storm water management; Japan's rain storage infiltration. The precipitation of Lin Yi city is mainly concentrated in the summer, the water system developed, the soil permeability of the higher ecological factor is the key factor to affect the construction of sponge city in Lin Yi city.

\section{A. Precipitations}

Lin Yi belongs to continental monsoon climate, annual rainfall of about $819 \mathrm{~mm}$, the seasonal distribution of precipitation is very uneven, $6,7,8$, three months of heavy rainfall (Fig .), heavy rain, heavy rain days accounted for $76.3 \%$ of the annual rainstorm, precipitation accounted for $62.5 \%$ of the annual rainfall. ${ }^{[5]}$ Heavy rainfall in Lin Yi city such as the July 8, 2012 of rainfall of $126 \mathrm{~mm}$; The annual change of precipitation in Lin Yi is large. The maximum annual rainfall of 1962--2007 is $1179.8 \mathrm{~mm}$ (1974), and the minimum annual rainfall is 
$510.4 \mathrm{~mm}$ (1988), and the annual precipitation is 2 times more than the maximum. ${ }^{[6]}$ Lin Yi belongs to continental monsoon climate, annual rainfall of about $819 \mathrm{~mm}$, the seasonal distribution of precipitation is very uneven, 6,7 , 8 , three months of heavy rainfall, heavy rain, heavy rain days accounted for $76.3 \%$ of the annual rainstorm, precipitation accounted for $62.5 \%$ of the annual rainfall. ${ }^{[7]}$ Heavy rainfall in Lin Yi city such as the July 8, 2012 of rainfall of $126 \mathrm{~mm}$; The annual change of precipitation in $\mathrm{Lin} \mathrm{Yi}$ is large. The maximum annual rainfall of 1962-2007 is $1179.8 \mathrm{~mm}$ (1974), and the minimum annual rainfall is $510.4 \mathrm{~mm}$ (1988), and the annual precipitation is 2 times more than the maximum. ${ }^{[8]}$

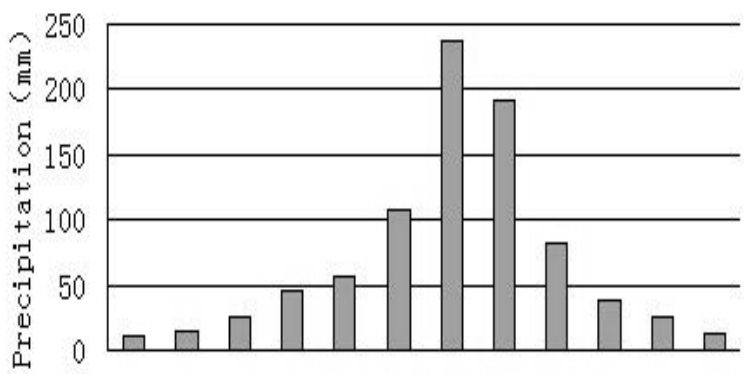

Jan Feb Mar Apr May Jun Jul Aug Sep Oct Now Dec

\section{Figure 1. Histogram of precipitation in Lin Yi City}

\section{B. Drainage systems}

The drainage system in Lin Yi city belongs to Yi River, drainage system in Lin $\mathrm{Yi}$ city is the main tributary of $\mathrm{Yi}$ river and river, which including Liu Qing River, Beng River, Su River, South Su River, Xianni River, Li Gong River, Qinglong River, etc(Figure 2). Yi River runs from north to south in Lin Yi city. Yi River is wide about 600$1530 \mathrm{~m}$, Yi River straight flat, beach width $50-200 \mathrm{~m}$; the construction of cascade dam formation water river about 31 Square kilometers of water, the total storage capacity of about 51000000 Cubic meters; Xiaobudong rubber dam was built in 1997, it is $1247.4 \mathrm{~m}$ in length, it is the first rubber dam of Lin Yi urban section, its maximum dam height of $3.5 \mathrm{~m}$, and the backwater length of $10.8 \mathrm{~km}$, the water storage area of 10.66 Square kilometers, the storage capacity of 28300000 Cubic meters of Yimeng lake. ${ }^{[9]}$

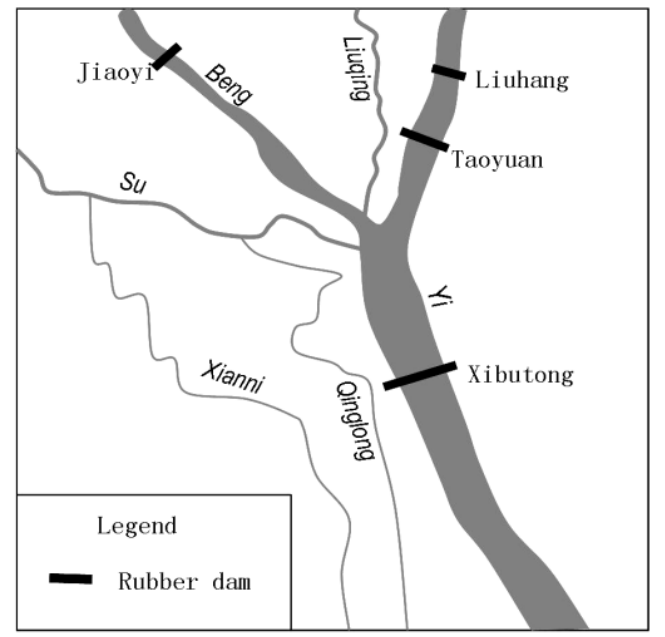

Figure 2. The main rivers of Lin Yi City

\section{Soil and vegetation}

The soil in Lin Yi city is mainly based on the sandy soil and the soil quality. Soil texture is loose and porous, permeable in Lin Yi city. Where soil is mainly quaternary alluvial soil, sandy soil, etc. Underlying bedrock mainly Cretaceous sandstone, andesitic, Carboniferous shakes Ordovician limestone.

Lin Yi urban vegetation is artificial vegetation, which including grassland, shrub, trees and a few patches of arbor and shrub forest land etc. Lin Yi city green less and scattered; urban river riverside area is concentrated green area. After ten years of green landscaping, Lin Yi city to reach Yi river, wetland, $\mathrm{Yi}$ river and its Beng River riparian green belt zonal ecological as the main body and communicated with each other. In 2014, the area of the built-up area of Lin Yi city was $42.1 \%, 37.24 \%$ and 13.72 Square meters. ${ }^{[7]}$ In 2014, the green coverage rate, green rate, per capita park green area of Lin Yi city in reached $42.1 \%, 37.24 \%$ and 13.72 sq. m respectively. Among them, the Yi River riparian green area of $18,000,000$ Square meters, Beng River riparian green area of 1,720,000 Square meters, Su River riverside greenbelt area of 580,000 Square meters, Xianni River riverside greenbelt area of 628,200 Square meters, Li Gong riverside greenbelt area of 980,000 Square meters. ${ }^{[10]}$

\section{THE PROBLEMS IN CONSTRUCTION OF SPONGE CITY}

Lin Yi city is a rapid development of the city, since the reform and opening up, Lin Yi city, the number of urban population, built-up area, green area, and so rapidly expanding. However, in the process of rapid urbanization in Lin Yi city, the city infrastructure is weak; the concept of sponge city has been ignored. Therefore, when the government advocates the construction of sponge City, some aspects and sponge city construction concept gap is very big.

\section{A. Urban planning lagged}

The existing urban master plan of Lin Yi city was established in 2005 year. It is the transformation from the traditional commerce and the development of modern logistics industry; combined with the advantages of water resources, improve the ecological green system and the construction of ecological garden city; improve the construction of regional culture, education, science and technology center to form a historical and cultural city with traditional culture and modern civilization; play aviation, highway, railway, built city traffic hub; provide employment and entrepreneurial opportunities, and the sustainable development of the livable city and city planning. The existing urban planning of Lin $\mathrm{Yi}$ city is lack of the construction of the sponge City, which can not meet the requirements of the construction of sponge city.

\section{B. Technology for local Sponge City construction is not yet mature}

Sponge city construction needs through the local natural climatic conditions, hydrology and water resources, topography, drainage district, river and lake water and wetlands, the water supply and demand, water pollution situation investigation, according to local conditions, the level of economic development and environment, in the economical use of land, taking into account other land, the 
principle of comprehensive and coordinated facility layout selection low-impact development techniques and facilities, giving priority to the use of the original green, river and lake water, natural ponds, waste land and other land with urban landscape planning and design, natural-based, supplemented by artificial facilities. At the same time, select suitable to local conditions to develop low-impact technology and facilities, including permeable paving, bioretention facilities, infiltration ponds, wet pond, rain wetlands, grass ditch, vegetation buffer zone. Sponge city construction concept quit a short time, for Lin Yi sponge local urban construction technology is still under exploration.

\section{Rainwater and sewage drainage system}

The wetland of Lin Yi city is about 50000000 cubic meters of water resources, Lin Yi city built-up area available 101000000 cubic meters ${ }^{[11]}$ of water directly into the city drainage system. At present, the drainage system in Lin Yi city by rainwater and sewage drainage system, the only Tongda road, the eastern section of Jiefang Road and other parts of the city to achieve rain and sewage diversion, urban rainwater through the urban drainage system into Xianni river, Qinglong River, Su River, North Liu Qing and other natural water systems, not only the utilization rate is low, but also easy to cause the natural river and its ecological zone pollution.

\section{Low Impact Development of storm water system construction projects are extremely lack}

Low Impact Development of rainwater system construction project is the starting point and basis of the construction of sponge City, the current Lin Yi city's water permeable pavement, green roof, sunken green space and square, living facilities, such as Low Impact Development of storm water system construction projects are extremely short. In 2014, the first use of rainwater utilization project of Lushang center of rainwater collection and utilization project put into operation in Lin Yi city, the precipitation after the initial rainwater storage module PP purification -automatic self--cleaning filter, ultraviolet disinfection, processing, storage for green watering etc. ${ }^{[12]}$

\section{COUNTERMEASURES}

The basic principles of the construction of the sponge city in China are planning to lead, ecological priority, safety, local conditions, and overall construction. Lin Yi city in the protection of rivers, lakes, wetlands, ponds and ditches water ecological sensitive area have identified important achievements. Therefore, the sponge city concept into urban planning and co-ordinate the pilot in Lin Yi city

\section{A. The concept of sponge city into urban planning}

Urban planning is a blueprint for urban development, construction and management. The concepts of sponge city into urban planning, construction implementation of lowimpact development storm water system content in the planning process; Lin $\mathrm{Yi}$ should be based on regional ecological characteristics, low-impact and actively carry out research and development, develop implementation strategies of urban low-impact development storm water systems, principles and implementation of regional focus, and the requirements and elements into detailed plan, through urban planning to sponge urban construction and make mandatory, leading sponge city construction in Lin Yi city.

\section{B. Suitable controlling index selection}

"Sponge City Construction Guide" based on China's nearly 200 cities 1983-2012 annual statistical analysis of daily rainfall, were obtained control of the cities of the total annual runoff of rainfall rate and the corresponding value of the relationship between design, will be divided into mainland China five boroughs, and gives the minimum and maximum limits for total annual runoff control rate $\alpha$ districts, that I area $(85 \% \leq \alpha \leq 90 \%)$, II region $(80 \% \leq \alpha \leq 85 \%)$, III zone $(75 \% \leq \alpha \leq 85 \%)$, IV region $(70 \%$ $\leq \alpha \leq 85 \%)$, V region $(60 \% \leq \alpha) .{ }^{[3]}$

The city has rivers in Lin Yi city, these rivers have been building reservoir dam, large capacity, heavy rainfall retention capacity, but heavy rain concentrated, and upstream river basin and precipitation nearly the same period, prone to floods; and the current municipal infrastructure capacity for precipitation transfusion lower part of the city tax severe storm, we must fully consider urban safety. Urban river water off more in Lin Yi city, urban water ecosystem in good condition. Linyi belonging annual runoff control rate in Zone IV, the total annual runoff control rate $\alpha$ the range is $70 \% \leq \alpha \leq 85 \%$, in view of the ecological status of the city and water safety, Linyi city, the total annual runoff control rates suitable index is $70 \%$, and the first implementation of the new urban development and construction projects, urban renewal projects urban Construction sponge individual projects.

\section{Accelerate the development of low-impact storm water exemplary system project}

City urban construction in full swing sponge does not meet the current urban situation in Lin Yi city, sponges accelerate urban construction should first exemplary lowimpact development storm water systems projects in Lin Yi city, such as selecting a large green area, rain and sewage discharge has been achieved or easy to implement rain and sewage diversion of schools, shopping malls, etc, to achieve urban precipitation resources, safety of rain, water environment optimization, aquatic landscaping purposes, forming sponge urban construction of demonstration projects; In the new urban construction, special planning sponge study of urban construction, detailed plan in Lin $\mathrm{Yi}$ city. Construction sponge accumulated data, to explore suitable for sponge Lin Yi city construction path.

\section{Improve the utilization of rainwater resources}

Strengthening urban rainwater resource utilization projects, improve the utilization of rainwater resources in Lin Yi city. The urban of Lin Yi rainwater pipes must strengthen network construction, rain water pipe network is liaison channel system throughout the precipitation resource on whether the precipitation resources to maximize the benefits from the regulatory role, Lin Yi city storm sewer drainage system as soon as possible rain and sewage diversion, and rainwater systems and low-impact development co-organized collection of rainwater runoff, transfusion and emission systems. At the same time, collection of rainwater resources at home and abroad for reference, using the technology and practice, combined 
with the regional situation of Lin Yi city urban area, choose appropriate rainwater utilization system, such as green on the infiltration system, roof rainwater collection system, road square rainwater collection resource recovery systems, etc.

\section{CONCLUSIONS}

Sponge city construction should adhere to planning guidance, indicators of compliance; achieve rain sewage diversion as soon as possible to improve the rate of rainwater resources in Lin Yi city.

Sponge city construction is to carry out low-impact development storm water system pilot project, step by step, the accumulation of experience.

The theory is still in the exploration and development stage of the sponge city, which needs to be further thought on the basis of accurate interpretation of its concept. The construction of the sponge city is based on Lin Yi city's regional ecological factors and urban infrastructure, as a case it has some limitations, but the corresponding method still has a certain reference value.

\section{REFERENCES}

[1] Canwei Hu. "Sponge City" Reconstruction urban water ecosystem[J].Ecological Economy, Vol. 31, No. 7 (July 2015)
[2] Baoxing Qiu. The connotation, Ways and Prospects of Sponge city(LID)[J]. Construction Science and Technology.2015(07):1118

[3] Ministry of housing and urban construction. Sponge city construction technology guide [EB/OL].http://www.mohurd.gov.cn/zcfg/jsbwj_0/jsbwjcsjs/20141 1/W020141102041225.pdf. 2015.10.21

[4] Kongjian Yu, Dihua Li, Hong Yuan. "Sponge City": Theory and Practice[J]. City Planning Review. Vol. 39 No.6 Jun. 2015:26-34

[5] Shuhan Zhang. "Sponge city" construction based on comprehensive utilization of urban rain and flood resources[J]. Construction Science and Technology.2015(07):26-28

[6] Dianmei Liu, Yurong Bai. Lin Yi city flood season rainstorm and flood [J]. Meteorological, 1999.04:52-54

[7] Hongqin Pei, Qingguo Tai, Ma Ni. Analysis of precipitation characteristics in Lin Yi city [J]. Anhui Agricultural Sciences. 2008, 36(28): $12356-12357$

[8] wenmin $\mathrm{Xu}$. Xiaopudong rubber dam: he people of Linyi to build the world's most [R]. http://lnsb.qlwb.com.cn/lnpaper/content/20140925/ArticelI04002Z G.htm.2015,11,21

[9] Cheng Zhuang. Lin Yi per capita area of parks and green spaces 13.72 square meters [R]. Yi Meng evening paper.2015.5.3

[10] Qian Fu. The Riverfront strait Added 11 Greenbelt [R]. Yi Meng evening paper. 2014,05,20

[11] Chong Yang, Ranhang Zhao, Qianjin Liu. Rainwater resource avail mode research of Lin Yi city [D].Jinan:Shandong University.2013

[12] Peng Zhu, Zhongzhi Jiao, Zi Min. Shandong Linyi city built the first rainwater harvesting sponge's project put into use[R]. LinYi Daily. 2015,05,11 